\title{
AXIOLOGICAL PARADIGM OF SOCIAL INCLUSION INTENSIFICATION - SELECTED REMARKS
}

\author{
Magdalena Matecka-Eyszczek, Radostaw Mędrzycki*
}

\begin{abstract}
This paper elaborates upon the values forming the axiological paradigm of social inclusion intensification. At its core, the analysis focuses on the examples found within the Polish legal system. The analysis has been conducted in consideration of such inclusive values as: dignity, freedom, equity, common welfare and social solidarity, which are commonly accepted as fundamental to all social inclusion actions of civil societies within countries established on the democratic rule of law. The analysis is to show that those values create the basis for actions performed in order to achieve social inclusion.
\end{abstract}

Key words: inclusion, axiology, dignity, common welfare

\section{PRELIMINARY REMARKS}

Our societies - the ones we live in, which we collectively establish and maintain within the emerging interconnected web of co-dependency and interaction of entities - are based on common principles and function in order to achieve and implement certain values. Those values bind our modern societies and their strength is tested by various hardships and crises which, in the end, prove the level of integrity and

Magdalena Małecka-Łyszczek, Associate Professor Hab., PhD, Departament of Constitutional and Administrative Law, and Public Procurement; Institute of Law; Cracow University of Economics, Radosław Mędrzycki, Associate Professor, PhD - Faculty of Law and Administration; Cardinal Stefan Wyszynski University in Warsaw. 
the will to overcome such critical emergencies by a society. Emergencies show whether or not a group is willing to fight, engage in solving the problem and, crucially, protect the values themselves. The values shared and followed by a group also directly influence and modify the inclusive activities dedicated towards the excluded members within a society. Consequently, when societies and groups are investigated, a certain margin is maintained in the form of an area in which some entities are not fully included within the structure of a given society. Such marginalisation does exist in varied shapes and forms ${ }^{1}$, nevertheless it is disadvantageous both to the excluded entity and the whole community (especially within societies based on the principles of solidarity). Social marginalisation, without any doubt, causes the society to be dysfunctional, especially if the community endeavours the maximisation of social inclusion and mitigation of exclusion. However, when the exclusion begins to increase, it is possible that it might grow uncontrollably and cross a critical point at which a society can no longer inhibit or stop it using its own resources (including both public administration and the various forms of a civil society). Such extensive exclusion could then stop being marginal and concern the majority of the society leading to an unstable societal condition. Consequently, societies rely on inclusive activities in order to remain healthy and effective. Such activities are, therefore, a necessity and must necessarily be included within any society in order to ensure proper co-existence. Such prevention mechanisms are thus formed by appropriate legislation and public policies - both nationwide and locally within various self-government structures (within the framework of specific national solutions) $)^{2}$. Meanwhile, the activities taken in order to empower the excluded are heavily axiologically pre-conditioned. The

For a comprehensive definition of exclusion consult: Jane Millar, "Social Exclusion and Social Policy Research: Defining Exclusion", In: Multidisciplinary handbook of social exclusion research, ed. Dominic Abrams, Julie Christian, David Gordon, Hoboken: Wiley-Blackwell, 2007, 1-15.

2 The specific activities may vary to a vast extent because inclusion does not mean the same to everyone. Not only can views of equity, participation and inclusion take different forms but they are also ideas that are continually evolving and developing. See also Jonathan Rix, Melanie Nind, Kieron Sheehy, Katy Simmons, John Parry, Rajni Kumari, Equality, Participation and Inclusion 2. Diverse Context, London, New York: Routledge, 2010. 
extent to which a society notices the issue of social exclusion indicates its respect for values which do (or should) lie at the core of a given society. Therefore, any and all inclusive activities constitute a demonstration of respect for human dignity, solidarity, common welfare, personal freedom and equity. Those values may be investigated from diverse angles and by various disciplines. This paper presents an analysis from the perspective of jurisprudence with reference to the Polish legal system. The ambiguity of the subject matter requires the study to be limited to positive law only - those social norms which are considered by the state to be common and applicable, i.e. referring to the regulation of those human activities which are performed in relation to other people ${ }^{3}$. Positive law gives a lawyer proper research opportunities for an adequate evaluation of the axiological bases for inclusion.

The paper attempts to present values which form the paradigm of social inclusion intensification with respect to Polish legislation. On the one hand, Polish solutions are rooted within the European civilization heritage, and on the other build and enhance it. From a broad perspective, the investigated phenomena touch upon general values shared by all the humanity, global principles existing regardless of cultural and legal variations.

Investigating values within law is not an easy task, and the difficulties appear to be universal regardless of place and culture. They mostly relate to the fundamental question of science: "what, how and why is anything investigated?" ${ }^{4}$ Such a study, contrary to potential justified expectations, is not an attempt to redefine values (which may, in the end, happen or be considered), but concerns the elementary ontological dilemmas: is value an element of the norm, an extra-normative category, a supposition on legislators goal, a fact in terms of social phenomena, or a motif shaping interpersonal relations? The literature also mentions methodological and teleological issues. The former is linked to the relation between values

3 Antoni Peretiatkowicz, Wstęp do nauk prawnych, Poznań: Księgarnia Wł. Wilak w Poznaniu, 1932, 15.

4 Zbigniew Cieślak, „Podstawy aksjologiczne administracji publicznej w Polsce próba oceny”, Studia Iuridica 38(2000): 60. 
and legal regulations ${ }^{5}$. The latter concerns the distinction of functionality and efficiency postulates, acknowledged especially within the study of administrative law. The administrative law study specifically aims at presenting the relation between values and the competence of legal regulations, specifically whether and to what extent they may be successfully implemented ${ }^{6}$.

Given the aforementioned observations, it is crucial to specify that from the ontological perspective the study of law is focused primarily on norms and regulations themselves. However, it does not imply an artificial division of the branches of law and legal study, e.g. the distinction between administrative and constitutional law. Since the study concerns the regulations, no other source should be necessary to reach conclusions other than the regulations themselves. Such an approach, as shall soon be proven, is not at odds with the existence of extra-legal values, which are simply not investigated herein. At this point, no philosophical approach to values (i.e. axiological objectivity or subjectivity ${ }^{7}$ ) must be adopted to provide a comprehensive study of the subject matter. Given those ontological presuppositions, values should only be investigated through an interpretation of law and regulations. It does imply a certain well-known difficulty - an analysis based solely on the interpretation of the law. This may lead to an extreme (but not baseless) objection, namely that every interpretation is strictly based on the interpreter's own views on the law, while the actual estimation is a result of the functional evaluation ${ }^{8}$. At this stage the investigator's bias may easily override the values intended to be represented within a regulation by the legislator. However, the ratio legis

5 Zbigniew Cieślak, „Podstawy aksjologiczne administracji publicznej w Polsce próba oceny”, Studia Iuridica 38(2000): 60.

6 See: Jan Zimmermann (Ed.), Aksjologia prawa administracyjnego, T. 1 and 2, Warszawa: Wolters Kluwer Polska 2017.

7 Tomasz Barankiewicz, „Aksjologiczna problematyka prawa”, Roczniki Nauk Prawnych 1(2004): 50. See also: Sławomir Fundowicz, „Aksjologia prawa administracyjnego", In: Koncepcja systemu prawa administracyjnego. Zjazd Katedr Prawa Administracyjnego i Postępowania Administracyjnego. Zakopane 24-27 września 2006, ed. Jan Zimmermann, Warszawa: Wolters Kluwer Polska 2007, 636-637.

8 Jerzy Leszczyński, „,Wartości prawa w teorii Jerzego Wróblewskiego”, Filozofia Publiczna i Edukacja Demokratyczna 2(2013): 260. 
of a regulation alone should prevent such far-reaching, presumably unintentional, manipulation', although the functional evaluation remains the crucial point of the analysis for the aforementioned reasons. Another issue, apart from proposing an unbiased description, relates to providing a certain hierarchy of values. On the surface, such an operation introduces subjectivity into the study, however, the law itself limits subjectivity of evaluation - each legal system uses certain axiomatic properties of the sources of law (e.g. the primary role of the constitution, generally accepted magnitude of properties of an investigated legal act inter alia). Therefore, the evaluation is always conducted with respect to the legislator, assuming their rationality in the legislative procedure.

Finally, the teleological bases for the analysis must be drawn. The aim of this paper is to reconstruct the values lying at the core of social inclusion and their reflection in both the constitutional matter and the administrative-law regulations.

By the will of the constitution lawmaker ${ }^{10}$, the Polish Constitution is the supreme law and legal act in Poland. The Constitution is thus the source of law in the positive law sense and takes precedence over any other legal acts and is a normative act as a whole ${ }^{11}$. From the formal perspective, the Constitution consists of the Preamble and 243 Articles. From the point of view of substantial systematics, it contains norms, rules and values $^{12}$. Rules and values are specifically difficult to distinguish as, according to the Polish jurisprudence, rules may also bear values, while not being values themselves ${ }^{13}$.

9 Jerzy Leszczyński, „Wartości prawa w teorii Jerzego Wróblewskiego”, Filozofia Publiczna i Edukacja Demokratyczna 2(2013): 260.

10 The constitution has been approved by the National Assembly of Poland (a joint chamber meeting of Sejm and Senat), approved by a national referendum on 25 May 1997.

11 Kazimierz Działocha, „Komentarz do art. 8”, In: Konstytucja Rzeczpospolitej Polskiej. Komentarz, ed. Leszek Garlicki, Marek Zubik, Warszawa: Wydawnictwo Sejmowe, 2016.

12 See. e.g. Marek Zubik, „O przewrotnych interpretacjach przepisów Konstytucji dotyczących władzy sądzenia”, Państwo i Prawo 10(2017):14.

13 Małgorzata Kordela, „Zasady prawa jako normatywna postać wartości”, Ruch Prawniczy, Ekonomiczny i Społeczny 1(2006): 39. 
Given the theses presented above, especially the purely normative view on values, it is crucial to address the specificity of Polish law, especially the horisontal and vertical effects of legal norms. Such an analysis is necessary from the perspective of hierarchy of values and presenting internal relations between those values, as shown in the further sections of this paper. The following sections will focus on respective values which have created the legal background for social inclusion.

\section{INCLUSIVE VALUES AND RELATED LEGAL SETTING}

\subsection{Dignity}

One of the most important values shared globally by the whole humanity, regardless of cultural or normative diversification is human dignity, and it must thus be recognised and protected for the security and development of the whole human kind. Various legal systems emphasise various aspects of human dignity, which reflects the understanding of this specific value within a community. Inclusion, as understood herein, is initiated and fuelled by the principle of respecting the human dignity. Inclusive actions are performed in order to restore one's dignity, granting them their lost agency, reinstating their self-worth, and encouraging them to actively participate in social life of a community, including the establishment of its internal structure and functioning. Inclusive actions are always grounded in the most elementary human values - the strongest ones which build the axiologically-rich sphere of human interaction within a society. Any analysis of social inclusion entails the question about the respect for human dignity, which brings us back to the Polish Constitution of 2997, which is the basis for all specific in-depth studies. The tenet of respecting the human dignity is one of the basic principles expressed within the Constitution expressis verbis, and is presented as the fundamental rule, one on which all other corresponding values may develop and flourish (Article 30). The related issue of the origin of humanity (i.e. when a being becomes a human being and a person) is linked to the philosophical and religious beliefs which form the basis for any legal system, especially: does dignity require only the emergence of a human being, or something more - a moral agent 
and experiencer capable of feeling ${ }^{14}$ ? The discussions rooted in various normative systems are reflected in respective legal solutions, for instance, the legal limitations concerning abortions. In this regard, Polish regulations are strongly influenced by the Christian worldview and philosophy. Thus, human dignity is undoubtedly both a value and a supreme law which takes precedence over all other values and laws. Moreover, it sets a universal and substantial axiological and normative perspective in relation to statutory law. It therefore determines the actions of the lawmakers and entities which apply the law ${ }^{15}$. All individual human rights stem from inherent human dignity, which makes human rights (ones attributed to every human being, regardless of nationality and other distinctive features) supranatural (primary, original), inalienable and inviolable ${ }^{16}$. In other words, the modern view on human rights derives all human rights from a single supreme and central value - the dignity of a human being ${ }^{17}$. Human dignity is therefore the source, the foundation, the primary norm (Grundnorm) in a logical, ontological and hermeneutical sense. All the other norms, rules and values found within the Constitution must be interpreted and applied in respect to dignity ${ }^{18}$. This marks dignity as special and sets it apart from any other concept, and makes it the reference point for the interpretation of any other values and norms related to the complexity of social inclusion and related issues and phenomena.

14 Alina Miruć, „Godność człowieka jako wyznacznik prawa administracyjnego stanowionego na szczeblu centralnym”, In: Aksjologia prawa administracyjnego, ed. Jan Zimmermann, Warszawa: Wolters Kluwer Polska: 2017, 420.

15 Alina Miruć, „Godność człowieka jako wyznacznik prawa administracyjnego stanowionego na szczeblu centralnym”, In: Aksjologia prawa administracyjnego, ed. Jan Zimmermann, Warszawa: Wolters Kluwer Polska: 2017, 420.

16 Wojciech Zakrzewski, „Podstawowe wolności, prawa i obowiązki człowieka i obywatela”, In: Polskie prawo konstytucyjne, ed. Wiesław Skrzydło, Lublin: Morpol 2001, 165. See also: Jack Donnelly, Universal Human Rights in Theory and Practice. Third Edition, London: Cornell University Press 2013, 1-4.

17 Bożena Gronowska, „Wolności, prawa i obowiązki człowieka i obywatela”, In: Prawo konstytucyjne, ed. Zbigniew Witkowski, Toruń: Towarzystwo Naukowe Organizacji i Kierownictwa. Stowarzyszenie Wyższej Użyteczności “Dom Organizatora” 2006, 173.

18 Leszek Garlicki, Polskie prawo konstytucyjne. Zarys wykładu, Warszawa: Liber 2007, 89 . 


\subsection{Freedom}

Dignity is not the only value important to the issue of social inclusion. In this section we will focus on Freedom, which on the surface is of little to no importance to the discussed topic, however, the selected examples will show that it should be a point of reference to social inclusion. In the case of the critically excluded, the relation between dignity and freedom, which may appear as a conflict between the two, may be successfully analysed.

One of the significant attributes of dignity, which makes it one of the basic laws in Poland, is the individual's freedom. This value is strongly linked not only to a person and dignity but also to the country and society, as it is the source of the right to be free on the one hand, and the obligation for the state to respect one's freedom, on the other ${ }^{19}$. How should the state respect and protect freedom? The state should address the issue of freedom primarily through its complex system of interconnected institutions; by establishing appropriate substantial laws, and finally through adequate procedures. Inclusive actions on all three aforementioned levels must be motivated by the value of human freedom. The following section presents all three levels from the perspective of freedom protection.

Freedom, as an element of social inclusion, is related to the situation of some people who face the issue of homelessness. It is worth mentioning that the erroneous classification of some homeless people as ones who chose homelessness as their way of living (homelessness by choice) is not specifically Polish but a global misunderstanding of the issue. Numerous sociological studies as well as experience shared by entities and organizations that provide help for the homeless have justly criticised the concept of "homeless by choice" ${ }^{20}$. Homelessness by choice is solely a type of a social rationalisation for the position of those who suffer long-term homeless-

19 Krzysztof Horubski, Leon Kieres, Tadeusz Kocowski,Marek Szydło, Artur Żurawik, „Podstawowe pojęcia publicznego prawa gospodarczego”, In: System prawa administracyjnego, 8A, ed. Roman Hauser, Zygmunt Niewiadomski, Andrzej Wróbel, Warszawa: C.H. Beck, 2018, 98.

${ }^{20}$ Ann Saltzman, Fred Curtis, "Social Distress Theory and Teaching About Homelessness: A Retrospective Analysis", Journal of Social Distress and the Homeless 2(1994): 118 and cited sources; Andrzej Przymeński, "Zjawisko bezdomności w Polsce współczesnej”, Polityka Społeczna 4(1998): 10. 
ness ${ }^{21}$. A homeless person is thus never truly free ${ }^{22}$. Attempting to restore (true) freedom becomes a major determinant of social inclusion. A proper organizational structure responsible for the protection of basic human rights in the context of axiological unity of law is required. Such a structure in Poland consists de iure of the central administration and the local municipal government, although it is the latter which, by the principle of subsidiarity, is expected to directly work to help the citizens escape homelessness. In reality, the administration outsources many of its tasks to non-public entities, with whom it is obliged to cooperate in a form of a partnership ${ }^{23}$.

From the perspective of the substantive law, freedom shall provide the opportunity to freely choose the available instruments provided by law in order to help one shape legal standing and fulfil demands. In a democratic rule-of-law state, solidarity and respect for human dignity cannot deprive one from claiming the rights solely due to living in social exclusion. The factual observation of exclusion must be separated from the legal realm in which social exclusion simply cannot exist. The merger of those two realms is a direct threat to democracy and the rule of law. Inclusive actions should lead to granting an individual the right to freely shape one's own legal situation.

21 Radosław Mędrzycki, Zadania w zakresie przeciwdziałania bezdomności. Studium administracyjnoprawne, Warszawa: Wydawnictwo UKSW 2017, 35 and cited sources especially Irena Lipowicz, "Uwagi wstępne: ku zmianie polityki publicznej w przeciwdziałaniu bezdomności”, In: Bezdomność - problemy prawne, innowacyjne rozwiązania, ed. Irena Lipowicz, Warszawa: Fundacja Didactics, 2017, 11; Jakub Wilczek, "Has the standardisation of homelessness services in Poland facilitated access to shelter?", Homeless in Europe Magazine Spring 2018: 4-6; Susan Yeich, The Politics of Ending Homelessness, Lanham: University Press of America, 1994, 5; on chronic homelessness: Craig Willse, The value of Homelessness. Managing surplus life in the United States, Minneapolis: University of Minnesota Press, 2015, 139-168.

22 The first suggests that homelessness is the result of an individual's actions and choices. The second, that it is the result of wider structural problems outside one's control: Graham Tipple, Suzanne Speak, The hidden millions: homelessness in developing countries, London, New York: Routledge, 2009, 4.

23 It is, naturally, an international tendency: Jeanne M. Wolfe, William Jay, "The Revolving Door: Third-Sector Organizations and the Homeless", In: Housing the Homeless and Poor. New Partnerships among the Private, Public and Third Sectors, ed. George Fallis, Alex Murray, Toronto: University of Toronto Press, 1990, 197-226. 
Last but not least there is the procedure which should be a value on its own during the application of any law, although it cannot limit or in any way hinder a person's ability to exercise the right due to social exclusion. In the case of the homeless, the questio diabolica of the procedure is found in the procedural requirement of a formal residence registration in order to be granted other laws. Although this issue has become less severe in recent years in Poland, mostly thanks to numerous open discussions about the consequences of a possible abolition of obligatory residence registration, it clearly remains the major issue of the procedure (in fact, such problems exist in other states as well ${ }^{24}$ ). On the other end of the spectrum there remains a justified reluctance, shared by a considerable number of the homeless, to undergo inclusive activities performed in the place where their homelessness originated. In a way, mandatory relocation of such a person (with no respect to one's freedom) to the last official place of residence, in case the procedural limitations prevent providing specialist care in the place of one's current residence (typically a city of one's choice), is at odds with the very idea of social inclusion and violates it. As such, the inclusive procedure must respect one's freedom.

\subsection{Equity}

The two values discussed so far were the background for inclusion. In this section equity as a goal of inclusivity is investigated. The Polish Constitution merges the principles of equity and non-discrimination into one normative unit ${ }^{25}$. The principle of equity originated in Ancient Greece (Plato, Aristotle) and refers to the achievements on the international (Universal Declaration of Human Rights, International Covenant on Civil and Political Rights, European Convention on Human Rights) and EU (Charter of Fundamental Rights of the European Union, Treaty on European Union, Treaty on the Functioning of the European Union) level ${ }^{26}$. It is

24 Aarolina Bednarz, Kwiaty w pudełku. Japonia oczami kobiet, Warszawa: Wydawnictwo Czarne, 2018, 180.

25 The 23 October 2001 Constitutional Tribunal ruling K 22/01, OTK ZU 2001 r., no 7.

26 We assume that inequity and equity refer to how fairly services, opportunities and access are distributed across groups of people or places, according to the need of that 
expressed not only in Articles 32 and $33^{27}$ but also in the Preamble to the Constitution where it is declared that all citizens are equal in their rights and responsibilities for their common welfare - Poland. In relation to groups of higher risk of exclusion, equity may take the form of a preferential treatment designed to improve their disadvantageous (exclusive) social situation. This concerns, among the others, national and ethnic minorities $^{28}$, children ${ }^{29}$, pregnant women, people with disabilities ${ }^{30}$ and the elderly ${ }^{31}$, families who have found themselves in a difficult financial and/ or social situation (especially large and incomplete families ${ }^{32}$ ). Such diversity stems directly from the application of the principle of justice, which allows for a differentiation of the social situation of specific units ${ }^{33}$. From the perspective of the values lying at the core of the inclusive actions, setting such compensatory privileges is in fact an axiologically determined

group. Mary Shaw, Bruna Galobardes, Debbie A. Lawlor, John Lynch, Ben Wheeler, George Davey Smith, The Handbook of Inequity and Socioeconomic Position: Concepts and Measures, Bristol: Bristol University Press, 2007, 13; Jay M. Shafritz, E.W. Russel, Christopher P. Borick, Albert C. Hyde, Introducing Public Administration, London, New York: Routledge, 2013, 433.

27 Article 32: 1. All persons shall be equal before the law. All persons shall have the right to equal treatment by public authorities. 2 . No one shall be discriminated against in political, social or economic life for any reason whatsoever.; Article 33: 1. Men and women shall have equal rights in family, political, social and economic life in the Republic of Poland. 2. Men and women shall have equal rights, in particular, regarding education, employment and promotion, and shall have the right to equal compensation for work of similar value, to social security, to hold offices, and to receive public honours and decorations.

28 Art. 27 par. 2 and art. 35 pt. 2 of the Constitution.

29 Additionally protected by art. 71 pt. 2 of the Constitution.

30 Additionally protected by Art. 69 of the Constitution.

31 Art. 68 pt. 3 of the Constitution.

32 Art. 71 pt. 1 par. 2 of the Constitution.

33 Consult the following constitutional Tribunal rulings: 3 September 1996 (K 10/96, OTK 1996, Nr 4, poz. 33), 24 February 2010 (K 6/09, OTK-A 2010, Nr 2, poz. 15). Regardless of the specific views on the principle of justice, it is agreed that internationally "the concept of social equity in public administration” is inextricably linked to J. Rawls's A Theory of Justice": Susan T. Gooden, "Social Equity in Public Administration. The Need For Fire", In: The Future of Public Administration Around the World: The Minnowbrook Perspective, ed. Rosemary O'Leary, David Van Slyke, Soonhee Kim, Georgetown: Georgetown University Press, 2010. 
duty of the lawmaker. The idea of the so called "positive discrimination" becomes an inseparable aspect of a society in which all groups and social categories can fully exercise their rights, regardless of their status. Only by expressing one's consideration for the weak can one show respect and acceptance of the diversity of the whole humankind ${ }^{34}$.

Although being two independent values, equity and solidarity are often strongly correlated with one another. Equity does not have to mean justice. In terms of inclusiveness, one tends to aim at just equity - equal opportunities. Those, however, do not have to have equal bases. Sometimes, in order to achieve equal opportunities, one must abandon equal bases in favour of positive discrimination.

\subsection{Common Welfare}

It is not possible to achieve inclusiveness without understanding the significance of the common welfare. This value allows for a deeper understanding of the goals of inclusiveness and compensatory actions leading to equity. Inclusive actions may be provided to any person suffering from social exclusion. The authors of this paper share a belief that Article 1 of the Polish Constitution stating that "The Republic of Poland shall be the common good of all its citizens" is limited and applies only to the citizens of Poland. An attempt to provide an axiological justification for an extension of inclusion to citizens of Poland and all foreigners or stateless persons must be based on the value of human dignity. Such an approach implies that every human being has dignity, regardless of citizenship. Moreover, inclusion - understood as reintegration of a unit with local community introduces a person into the whole realm of a unique value, which is the Republic of Poland. It might appear that the Republic of Poland on its own cannot serve as a justification for social inclusion. However, as a common welfare it "shall constitute the general conditions of a social existence which, either through associations or individual members of the community, allow for a full and easier achievement of individual perfection"; the common welfare, therefore, is the source of solidarity and the principles

34 Marek Safjan, Przemysław Mikłaszewicz, „Granice uprzywilejowania wyrównawczego", Przegląd Sejmowy 6(2011): 36. 
of democracy ${ }^{35}$. Human dignity, freedom and solidarity must be unconditionally respected if the state - the Republic of Poland - is to prevail as the common welfare, and must be enforced if the bodies of the state are to be in full servitude to the citizens ${ }^{36}$.

\subsection{Social Solidarity}

Last, but not least, the value of solidarity, which is strongly associated with common welfare and other values presented so far, needs to be elaborated upon. Solidarity is important for respecting other inclusive values. It is also one of the values mentioned in the Polish Constitution.

Social inclusion with full respect to dignity and freedom inevitably leads to certain objections. Why should the majority participate in the costs of inclusion of those who have "removed themselves" outside the bounds of society and become excluded? Why should the general community want to restore freedom, equity and do it in the name of common welfare? Inclusion would not be possible if not for social solidarity, which is the underlying source of inclusion and shows the actual worth of all other values.

The legal understanding and expression of solidarity is, in a way, paradoxical. The notion itself has gone a long way from the Roman law, through the immense philosophical and political discourse of modern times to be defined anew (both in its role and characteristics) and enter the legal systems ${ }^{37}$. Clearly, neither are the authors of this publication focused on a full investigation of the philosophical aspects and context in which

35 Such a definition of the common welfare is expressed in the encyclic Gaudium et spes. Sławomir Fundowicz, „Aksjologia prawa administracyjnego”, In: Koncepcja systemu prawa administracyjnego. Zjazd Katedr Prawa Administracyjnego i Postępowania Administracyjnego. Zakopane 24-27 września 2006, ed. Jan Zimmermann, Warszawa: Wolters Kluwer Polska 2007, 647.

36 Irena Lipowicz, „Dobro wspólne”, Ruch Prawniczy, Ekonomiczny i Socjologiczny 3(2017): 19.

37 Dariusz Dobrzański, „Nowożytna idea solidarności”, In: Idea solidarności w kontekstach filozoficzno-historycznych, ed. Dariusz Dobrzański, Andrzej Wawrzynowicz, Poznań: Wydawnictwo Instytutu Filozofii UAM, 2006, 13. 
solidarity is found, nor would such a brief description be possible ${ }^{38}$. Suffice to say that due to this long and complex way from the ancient to modern concept of solidarity, full of philosophical twists and turns, this concept and value has diverged from the simple notion of joint liability. This recognised history of the idea, however, hinders the ability to propose a simple explication, especially that solidarity is an ideological and a normative concept found both on the individual and collective level ${ }^{39}$. The semantic and pragmatic complexity granted to solidarity by philosophy makes the concept non-uniform: the more information is discovered, the less defined it becomes. For the purpose of this paper, only general attributes of solidarity shall be selected and used for future reference. Such an approach will underline only the most important themes, while presenting the diversified approach to social inclusion.

The "core" of solidarity, or the common understanding of solidarity, is the relation of mutual dependency between individual members of a community $^{40}$ and the community as a whole ${ }^{41}$. Any further investigation into the notion of solidarity requires it to be expressed as a legal concept. It is thus a relation which becomes substance; an internal interdependence of community members and the care of ones for the others is a direct result of shared responsibility for all members of the same community ${ }^{42}$. Naturally, the "whole" may be defined in many ways depending on the context: as family, self-governed community, nation, international community, the humanity or even all living beings. Solidarity may also apply

38 Those have been investigated in detail in: Dariusz Dobrzański, Zasada solidarności. Studium z filozofii społecznej, Poznań: Wydawnictwo Naukowe UAM, 2013.

39 Also consult: Arto Laitinen, Anne Birgitta Pessi, "Solidarity: Theory And Practice. An Introduction", In: Solidarity. Theory and Practice, ed. Arto Laitinen, Anne Birgitta Pessi, London: Lexington Books 2015, 5; Aafke Komter, "Solidarity", In: International Encyclopedia of Civil Society, ed. Helmut. A. Anheier, Stefan Toepler, New York: Springer -Verlag, 2010, 1460-1461.

40 An „independent” context is also possible, however it shall be omitted as unrelated to the subject matter. Dariusz Dobrzański, „Nowożytna idea solidarności”, In: Idea solidarności w kontekstach filozoficzno-historycznych, ed. Dariusz Dobrzański, Andrzej Wawrzynowicz, Poznań: Wydawnictwo Instytutu Filozofii UAM, 2006, 14.

${ }^{41}$ Charles Gide, "Solidarity", In: The New Palgrave Dictionary of Economics, ed. John Eatwell, Murray Milgate, Peter Newman, London: Palgrave Macmillan, 2018, 1.

42 Compare: Émile Durkheim, De La Division Du Travail Social, Paris: PUF, 2007. 
to other categories, such as age where it becomes intergenerational. Irena Lipowicz rightly notices that "Solidarity directs joint actions, teaches how to bear the burdens of others, it helps a person or even nation leave the bounds of their self-centred interests. It is beneficial for the whole nation throughout its continued existence" ${ }^{43}$. Similarly, Ingolf Price described solidarity as the idea of the community itself, a "qualified bond" shared by its members ${ }^{44}$. It then begs a question of whether solidarity creates a community, or the community creates (the need for) solidarity ${ }^{45}$. How should social solidarity be understood?

It may sometimes be difficult to distinguish two similar concepts from each other, as it is in the case of solidarity and charity. In principle, charity exists in vertical relations and is associated with compassion while solidarity, which builds a community, is based on horizontal relations. The scope is also different: for charity it is the "I", while solidarity is motivated by "us." ${ }^{46}$ In some views, charity is seen as one which does not require reciprocation, while solidarity may in certain cases be mutual (the exchange of goods, benefits, values $)^{47}$. On the surface, social inclusion should be motivated by charity more than solidarity. Any expectation of some kind of "return" from the one who is being included would be virtual, especially if the return were to comprise similar goods as those utilised in the process of inclusion. However, the realisation of an individual interest (of the excluded) during the legal and legally-based inclusion should always entail a public (community's) interest or even personal (i.e. a specific person's)

43 Irena Lipowicz, „Dobro wspólne”, Ruch Prawniczy, Ekonomiczny i Socjologiczny 3(2017): 20.

44 Ingolf Pernice, „Solidarność w Europie. Miejsce w relacjach między obywatelem, państwem i Unią Europejską, part I”, Europejski Przegląd Sądowy 10(2013): 5.

45 The author seems to be a proponent of the latter, as only by the use of the EU instruments may solidarity fully emerge. Ingolf Pernice, „Solidarność w Europie. Miejsce w relacjach między obywatelem, państwem i Unią Europejską”, part I, Europejski Przegląd Sądowy 10(2013): 49.

46 Arto Laitinen, Anne Birgitta Pessi, "Solidarity: Theory And Practice. An Introduction", In: Solidarity. Theory and Practice, ed. Arto Laitinen, Anne Birgitta Pessi, London: Lexington Books 2015, 15.

47 Arto Laitinen, Anne Birgitta Pessi, "Solidarity: Theory And Practice. An Introduction”, In: Solidarity. Theory and Practice, ed. Arto Laitinen, Anne Birgitta Pessi, London: Lexington Books 2015, 12. 
achievement. Consequently, even if its transactional nature is to be concerned, solidarity is strictly correlated with social inclusion.

Solidarity helps with enforcing various values while being a value itself. The positive axiological context of solidarity is unsurprising, although one can name certain "deviations", such as an instance of strong solidarity shared by a group which manifests itself as aversion to others. On the other hand, one could wonder if solidarity could be compulsory, yet it is believed that compulsory solidarity is simply not possible. In a prosperous country the duties and actions taken for the sake of others may only be motivated and justified by solidarity ${ }^{48}$. The authors of this paper share the (somewhat subjective) view that solidarity should never be used for "exploitation for exploitation's sake", but a kind of "exploitation" of oneself to serve the others. A person is the only and sufficient source and reason for solidarity.

The Preamble to the Polish Constitution clearly references solidarity by stating that "all those who will apply this Constitution for the good of the Third Republic to do so paying respect to the inherent dignity of the person, his or her right to freedom, the obligation of solidarity with others, and respect for these principles as the unshakeable foundation of the Republic of Poland ${ }^{49}$." It is therefore crucial to address the potential effect of mentioning solidarity in the Constitution, as it is necessary to properly understand the normative context in which this expression is found and its further consequences. Solidarity on its own is an inclusive value, historically legally linked with poverty prevention ${ }^{50}$, yet it must also be supported by the analysed contemporary normative data.

48 Dariusz Dobrzański, „Nowożytna idea solidarności”, In: Idea solidarności w kontekstach filozoficzno-historycznych, ed. Dariusz Dobrzański, Andrzej Wawrzynowicz, Poznań: Wydawnictwo Instytutu Filozofii UAM, 2006, 40.

49 Such a direct mention of solidarity may also be found in Article 20 of the Constitution, yet it concerns a matter distant from the topic of this paper and thus shall not be investigated. The Article governs the economy and states: „A social market economy, based on the freedom of economic activity, private ownership, and solidarity, dialogue and cooperation between social partners, shall be the basis of the economic system of the Republic of Poland."

50 Philipp Dann, "Solidarity and the Law of Development Cooperation", In: Solidarity: A Structural Principe Of International Law, ed. Rudiger Wolfrum, Chie Kojima, Heidelberg, New York: Springer 2010, 56. 
The analysis of the Preamble to the Constitution leads to the conclusion that it has at least partial normative nature, assuming that the normative nature of the Preamble implies its direct application - it would entrust the duties and responsibilities of a certain state or self-government (and other) entities to public administration. The Preamble sets "the obligation of solidarity with others", which is grounded in the following position "I do not require charity from anyone (assuming vertical, not horizontal relationship $)^{51}$, set in personal compassion or mercy, but a paradigm of a modern democracy - every man is equal." Regardless of the view on the necessity of inclusion of those socially excluded, the Polish Constitution points to the obligation to bear the consequences stemming from solidarity (such as taxes, positive discrimination, etc.). This makes solidarity a normative imperative for the actions of the state and its members, initially motivated by the need of human dignity protection.

The Preamble is proprietary and serves as a reference point for the understanding of the purpose of specific regulations, allows for a better understanding of their ratio legis, and helps us better our understanding of the relations between respective regulations within a legal act ${ }^{52}$. Moreover, due to the position of the Constitution within the Polish legal system, the Preamble serves as the point of reference for contextualizing the whole legal system and is invaluable in the process of interpretation of statutory acts $^{53}$. Therefore, by maintaining an axiological uniformity of the Polish law, one must attempt to understand the law from the perspective of the principle of solidarity. Naturally, the interpretation may neither fix bad law nor create a new regulation.

51 Philipp Dann, "Solidarity and the Law of Development Cooperation", In: Solidarity: A Structural Principe Of International Law, ed. Rudiger Wolfrum, Chie Kojima, Heidelberg, New York: Springer 2010, 57.

52 Leszek Leszczyński, „Wykładnia celowościowo-funkcjonalna przepisów prawa administracyjnego", In: Wykładnia w prawie administracyjnym. System Prawa Administracyjnego, ed. Roman Hauser, Andrzej Wróbel, Zygmunt Niewiadomski, Warszawa: C.H. Beck, 2015, 294.

53 The Supreme Administrative Court of Poland rulings: 30 October 2010, I OSK 2060/14, CBOSA; 23 October 2015, I OSK 456/14. 


\section{FINAL REMARKS}

All the values presented in this paper coexist with one another. It is not possible (nor should it ever be attempted) to artificially separate them - only when they intertwine, complete and enhance one another can the inclusive actions be designed and executed in the most advantageous manner. The values and related principles are connected and, therefore, their interpretation in the context of law application must also be done from the perspective of their coexistence and mutual influence. However, our goal has never been to provide an in-depth analysis of the connections between the discussed values, their coexistence and significance for social inclusion appears to be unquestionable. Each of the discussed values takes part in the establishment of the resources shared by a democratic state and by the internal structures of the civil society existing within this state's bounds. They are the basis and an inherent attribute of modern civilized societies, while remaining complementary for one another. Only by taking them all into consideration can we provide an adequate and comprehensive understanding of inclusivity and achieve its desired model.

All the values presented in this paper justify social inclusion, although solidarity stands out as the one binding them all together. The goal of social inclusion from the perspective of solidarity requires the legal debate to include other values, specifically the ones discussed in this paper. Dignity presents all human beings as worthy of inclusion. Freedom stresses the need for being included, as only by being fully included in a society can one be truly free (exclusion is the denial of freedom). Common welfare lets the inclusion reach beyond the national bounds. Finally, equity, from the perspective of justice, lets the excluded to have access to the welfare as a whole and provides for equal opportunities.

\section{REFERENCES}

Barankiewicz, Tomasz. 2004. „Aksjologiczna problematyka prawa”. Roczniki Nauk Prawnych 1: 45-58.

Bednarz, Karolina. 2018. Kwiaty w pudełku. Japonia oczami kobiet. Warszawa: Wydawnictwo Czarne. 
Cieślak, Zbigniew. 2000. „Podstawy aksjologiczne administracji publicznej w Polsce - próba oceny”. Studia Iuridica 38:59-64.

Dann, Philipp. 2010. "Solidarity and the Law of Development Cooperation", In: Solidarity: A Structural Principe Of International Law, ed. Rudiger Wolfrum, Chie Kojima, Heidelberg, 55-91. New York: Springer.

Dobrzański, Dariusz. 2006. „Nowożytna idea solidarności”. In: Idea solidarności w kontekstach filozoficzno-historycznych, ed. Dariusz Dobrzański, Andrzej Wawrzynowicz. 11-40. Poznań: Wydawnictwo Instytutu Filozofii UAM.

Dobrzański, Dariusz. 2013. Zasada solidarności. Studium z filozofii społecznej, Poznań: Wydawnictwo Naukowe UAM.

Donnelly, Jack. 2013. Universal Human Rights in Theory and Practice. Third Edition, London: Cornell University Press.

Durkheim, Émile. 2007. De La Division Du Travail Social, Paris: PUF.

Frideres, James, John Biles. 2012. "Introduction". In: International Perspectives: Integration and Inclusion, ed. James Frideres, John Biles, Montreal, 1-14. Montreal: McGill-Queen's University Press.

Fundowicz, Sławomir. 2007. „Aksjologia prawa administracyjnego”. In: Koncepcja systemu prawa administracyjnego. Zjazd Katedr Prawa Administracyjnego i Postępowania Administracyjnego. Zakopane 24-27 września 2006, ed. Jan Zimmermann, 633-654. Warszawa: Wolters Kluwer Polska.

Garlicki, Leszek. 2007. Polskie prawo konstytucyjne. Zarys wykładu. Warszawa: Liber.

Gide Charles. 2018. "Solidarity”. In: The New Palgrave Dictionary of Economics, ed. John Eatwell, Murray Milgate, Peter Newman, 1-2. London: Palgrave Macmillan.

Gooden, Susan T. 2010. "Social Equity in Public Administration. The Need For Fire". In: The Future of Public Administration Around the World: The Minnowbrook Perspective, ed. Rosemary O'Leary, David Van Slyke, Soonhee Kim. 55-58. Georgetown: Georgetown University Press.

Gronowska, Bożena. 2006. „Wolności, prawa i obowiązki człowieka i obywatela”. In: Prawo konstytucyjne, ed. Zbigniew Witkowski, 157-209. Toruń: Towarzystwo Naukowe Organizacji i Kierownictwa. Stowarzyszenie Wyższej Użyteczności “Dom Organizatora”.

Horubski, Krzysztof, Leon Kieres, Tadeusz Kocowski, Marek Szydło, Artur Żurawik. 2018. „Podstawowe pojęcia publicznego prawa gospodarczego”. In: System prawa administracyjnego, 8A, ed. Roman Hauser, Zygmunt Niewiadomski, Andrzej Wróbel, 41-458. Warszawa: C.H. Beck. 
Komter, Ananke. 2010. "Solidarity”. In: International Encyclopedia of Civil Society, ed. Helmut. A. Anheier, Stefan Toepler, 1460-1461. New York: Springer -Verlag.

Kordela, Małgorzata. 2006. „Zasady prawa jako normatywna postać wartości”. Ruch Prawniczy, Ekonomiczny i Społeczny 1:39-54.

Laitinen, Arto, Anne Birgitta Pessi. 2015. "Solidarity: Theory And Practice. An Introduction". In: Solidarity. Theory and Practice, ed. Arto Laitinen, Anne Birgitta Pessi, 1-29. London: Lexington Books.

Leszczyński, Jerzy. 2013. „Wartości prawa w teorii Jerzego Wróblewskiego”. Filozofia Publiczna i Edukacja Demokratyczna 2: 258-272.

Leszczyński, Leszek. 2015. „Wykładnia celowościowo-funkcjonalna przepisów prawa administracyjnego". In: Wykładnia w prawie administracyjnym. System Prawa Administracyjnego, ed. Roman Hauser, Andrzej Wróbel, Zygmunt Niewiadomski, 283-324. Warszawa: C.H. Beck.

Lipowicz, Irena. 2017. „Dobro wspólne”. Ruch Prawniczy, Ekonomiczny i Socjologiczny 3: 17-31.

Lipowicz, Irena. 2017. "Uwagi wstępne: ku zmianie polityki publicznej w przeciwdziałaniu bezdomności". In: Bezdomność - problemy prawne, innowacyjne rozwiązania, ed. Irena Lipowicz, 7-13. Warszawa: Fundacja Didactics.

Mędrzycki, Radosław. 2017. Zadania w zakresie przeciwdziałania bezdomności. Studium administracyjnoprawne. Warszawa: Wydawnictwo UKSW.

Millar, Jane. 2007. "Social Exclusion and Social Policy Research: Defining Exclusion", In: Multidisciplinary handbook of social exclusion research, ed. Dominic Abrams, Julie Christian, David Gordon, 1-15. Hoboken: Wiley-Blackwell. Miruć, Alina. 2017. „Godność człowieka jako wyznacznik prawa administracyjnego stanowionego na szczeblu centralnym". In: Aksjologia prawa administracyjnego, ed. Jan Zimmermann, 419-434. Warszawa: Wolters Kluwer Polska.

Peretiatkowicz, Antoni. 1932. Wstęp do nauk prawnych. Poznań: Księgarnia Wł. Wilak w Poznaniu.

Pernice, Ingolf. 2013. „Solidarność w Europie. Miejsce w relacjach między obywatelem, państwem i Unią Europejską, part I”. Europejski Przegląd Sądowy 10:4-9.

Przymeński, Andrzej. 1998. "Zjawisko bezdomności w Polsce współczesnej”. Polityka Społeczna 4:8-11.

Rix, Jonathan, Melanie Nind, Kieron Sheehy, Katy Simmons, John Parry, Rajni Kumari. 2010. Equality, Participation and Inclusion 2. Diverse Context, London, New York: Routledge.

Safjan, Marek, Przemysław Mikłaszewicz. 2011. „Granice uprzywilejowania wyrównawczego". Przegląd Sejmowy 6: 31-46. 
Saltzman, Ann, Fred Curtis. 1994. "Social Distress Theory and Teaching About Homelessness: A Retrospective Analysis". Journal of Social Distress and the Homeless 2: 99-133.

Shafritz, Jay M., E.W. Russel, Christopher P. Borick, Albert C. Hyde. 2013. Introducing Public Administration. London, New York: Routledge.

Shaw, Mary, Bruna Galobardes, Debbie A. Lawlor, John Lynch, Ben Wheeler, George Davey Smith. 2017. The Handbook of Inequity and Socioeconomic Position: Concepts and Measures. Bristol: Bristol University Press.

Tipple, Graham, Suzanne Speak. 2009. The hidden millions: homelessness in developing countries. London, New York: Routledge.

Wilczek, Jakub. 2018. "Has the standardisation of homelessness services in Poland facilitated access to shelter?", Homeless in Europe Magazine. Spring: 4-6.

Willse, Craig. 2015. The value of Homelessness. Managing surplus life in the United States. Minneapolis: University of Minnesota Press.

Wolfe, Jeanne M., William Jay. 1990. "The Revolving Door: Third-Sector Organizations and the Homeless". In: Housing the Homeless and Poor. New Partnerships among the Private, Public and Third Sectors, ed. George Fallis, Alex Murray, 197-226. Toronto: University of Toronto Press.

Wszołek, Przemysław. 2015. Kryteria wyodrębniania prawa administracyjnego. Warszawa: Wolters Kluwer Polska.

Yeich, Susan. 1994. The Politics of Ending Homelessness. Lanham: University Press of America.

Zakrzewski, Wojciech. 2001. „Podstawowe wolności, prawa i obowiązki człowieka i obywatela”. In: Polskie prawo konstytucyjne, ed. Wiesław Skrzydło, 161-186. Lublin: Morpol.

Zubik, Marek. 2017. „O przewrotnych interpretacjach przepisów Konstytucji dotyczących władzy sądzenia”. Państwo i Prawo 10:5-19. 
